Institutional Report

\title{
Recent Advancement(s) at the Birbal Sahni Institute of Palaeosciences, Lucknow: An Overview
}

\author{
SANTOSH K SHAH, VIVESH V KAPUR, M C MANOJ, JYOTI SRIVASTAVA and VANDANA PRASAD* \\ Birbal Sahni Institute of Palaeosciences, 53 University Road, Lucknow 226 007, India
}

\section{Introduction}

Bestowed with the legacy of Prof. Birbal Sahni for deciphering the evolutionary history of Kingdom Plantae through the study of plant fossils, the Birbal Sahni Institute of Palaeosciences (BSIP), erstwhile Birbal Sahni Institute of Palaeobotany has grown manifold in the fields of the evolutionary history of plants, palaeoclimate, and palaeoecology. The establishment of new instrumentation facilities and the induction of scientists has led to the development of the BSIP in recent years. Presently, this institute's research activities include the study of plant fossils, and associated micro- and macrofossils (palynomorphs, nannofossils, diatoms and others), insects, vertebrates, palaeo-climates, -environments, -ecosystems, -biogeography, -archaeobotany, biostratigraphy, geochemistry, fossil fuel exploration, carbon dating, DNA sequencing and development of analytical techniques. This overview highlights some noteworthy research activities carried out from January 2016 to March 2019 and discusses the significance of these research contributions in developing an understanding of the fossil records in terms of deciphering the evolutionary history of biotapast ecosystem and climatic changes through the earth's history.

Within the realm of the existing mandate, the BSIP executes multidisciplinary research in the field of Palaeosciences. A total of sixty-one project components were incorporated under ten major projects which include:

1. Early life and environment: Evidence from Indian Precambrian basins.

2. Emergence, biotic crisis, adaptation and radiation

*Author for Correspondence: E-mail: director@bsip.res.in of life forms during Paleozoic and Mesozoic: An integrated approach.

3. Palaeobiogeography, biotic and climatic events, characterization of the biomarker in the terminal Cretaceous-early Palaeogene sequences of India.

4. Understanding monsoonal variability and its relationship with the global climate during the Neogene using biotic and abiotic proxies.

5. Vegetation dynamics and palaeoclimate of late Quaternary sequences of the Himalayan region.

6. Monsoonal variability and climate change during late Quaternary in Peninsular India inferred from palaeovegetation.

7. Late Quaternary Palaeoclimate and palaeoceanographic variability from marine records.

8. Holocene monsoonal variability and its associated forcing factors inferred from abiotic proxies.

9. Archaeology, Archaeochemistry, Palaeogenomics/metagenomics: Implications to humanenvironment interaction during the Holocene.

10. Laboratory establishment and protocol development for new proxy parameters and smooth functioning of sophisticated analytical facilities.

Several analytical facilities/laboratories that include X-Ray Fluorescence Laboratory, Nutrient Analyzer Facility, Vertebrate Palaeontology and Preparation Laboratory, Ancient DNA Laboratory, and Modern DNA Laboratoryhave been set up within BSIP, since 2016 (Refer link: www.bsip.res.in). BSIP 
scientists are actively involved in providing help to Oil and Natural Gas Corporation, Oil India Limited, Coal India Limited, and Archaeological Survey of India, in studies involving palaeobotanical and micropalaeontology aspects, in addition to their institutional research activities.

\section{Highlights}

\section{Precambrian}

Palaeobiological and chemostratigraphic records from Indian Proterozoic successions are well robust to solve the riddle of evolution and diversification of early life. A considerable large dataset on palaeobiology, geochronology, and chemostratigraphy from the Indian Precambrian sedimentary basins is available. Because of the above aspects, palaeobiological evidence of Indian Palaeoproterozoic to Cambrian successions (Sharma et al., 2016; Sharma and Singh, 2019) and new prospects of the Bijaigarh Shale (Ansari, 2017) were appraised. A new enigmatic Ediacaran form (putative seaweed) from the Sonia Sandstone (Marwar Supergroup) was reconstructed (Kumar and Ahmad, 2016; Pandey and Sharma, 2017). Organic walled microfossils were studied in a biostratigraphic framework from the Kurnool Group, Chattisgarh, and Vindhyan supergroups (Singh and Sharma, 2016; Sharma and Shukla, 2016; Shukla and Sharma, 2016). Stable isotopic studies from the Marwar Supergroup and the Garbyang Formation (Tethys Himalaya) suggest the presence of Precambrian-Cambrian boundary within these successions (Ansari et al., 2018, 2019). Two significant trace fossils (Treptichnus pedum and Monomorphichnus multilineatus) from the Nagaur Sandstone (Marwar Supergroup, Rajasthan) were studied to understand change(s) in the Precambrian-Cambrian ecosystem (s) (Sharma et al., 2018a, 2018b). In Astrobiological context, modern geo-site(s) (e.g., Ladakh: as an off-Earth analog) and Precambrian rock sequences were explored by BSIP scientists (Pandey et al., 2019; Steller et al., 2019). Recently, Sharma and Shukla (2019) documented the existence of ancient life in extreme environments based on Akinites from the Vindhyan Supergroup. In a collaborative study, Limaye et al. (2018) revealed the possibility of life in the spectral signature reflected from the cloud of planet Venus. This study has opened newer opportunities for exploring life's signature(s) in different planets.
Previously, modern glaciers and their catchment areas were studied to understand the sulfur and nitrogen pathways to comprehend similar ancient environments (Ansari et al., 2016a, 2016b).

\section{Palaeozoic-Early Mesozoic}

Palynological studies, supplemented by detrital zircon $\mathrm{U}-\mathrm{Pb}$ ages, from the Fenestella Shale Formation (Carboniferous) near the Gund Village in the Banihal area of Jammu and Kashmir State, India have been carried out for the first time (Agnihotri et al., 2018). Geochemistry of the Permian-Triassic sequences of the Guryul Ravine section, Jammu and Kashmir, India, reveals implications for oceanic redox conditions (Kumar et al., 2017). Evidence of repeated fire events in the Early Permian 'peat-forming' vegetation of India has been detected (Jasper et al., 2017). The Lower Triassic deposits represent hot-arid conditions along with the braided river systems (Mishra et al., 2017). Palynological and petrological studies undertaken on the Gondwana coal and associated lithologies encountered in borehole EBM-2 of East Bokaro coalfield of Damodar Basin, India were used to determine the depositional environment of the coal precursor peat swamp (Murthy et al., 2016). Permian (Lower Gondwana) and Late Jurassic-Early Cretaceous (Upper Gondwana) palynomorphs and megafossils have been recorded from Nimugudem area, Godavari sub basin, Telangana, India (Jha et al., 2016). A new species of fossil wood, Circoporoxylon kotaense, was systematically described from the Jurassic Kota formation, in the Pranhita-Godavari Basin, India (Chinnappa and Rajanikanth, 2016). The palaeoenvironmental reconstruction of freshwater sequences in the LingalaKoyagudem Coal belt of the Godavari Graben, using palynofacies was carried out by Agarwal et al. (2019). Murthy et al. (2018) documented, for the first time, the palynological assemblage from the Rajmahal basin, probably from the Late Pennsylvanian age. Diverse macrofloral assemblage recovered from TatapaniRamkola Coalfield, Son-Mahanadi Basin, India suggested that plant life was gradually transformed and evolved near Raniganj-Panchet boundary, rather than a taxonomic turnover (Saxena et al., 2019). A review of the palynostratigraphy of Gondwana sediments from Godavari Graben, India with a global comparison and correlation of Permian-Triassic palynoflora was also carried out by Jha et al. (2018). 


\section{Late Cretaceous-Cenozoic}

BSIP has been conducting significant research to trace the early evolutionary history of angiosperms in a palaeobiogeographic framework. Institute's scientists have been continuously exploring plant fossils and associated microbiota from within the Late Cretaceous-early Palaeogene Deccan volcanosedimentary sequences of peninsular India and the Palaeogene-Neogene sedimentary sequences in the western and northeastern regions of India. In a recent collaborative study by BSIP, scientists have recorded the earliest fossil record of the family Connaraceae within the Late Cretaceous-early Palaeogene intertrappean beds of central India (Bass et al., 2017). Kathal et al. (2017) recorded Nypa (Rhizopalmoxylon nypoides) from the late Maastrichtian-early Danian intertrappean beds of central India that indicated marine influence in the region. An assemblage of microfossils consisting of non-marine ostracods, charophyte gyrogonites, mollusks, and fish remains were reported from a new Late Cretaceous intertrappean locality near the town of Manawar, District Dhar, Madhya Pradesh, Central India (Kapur et al., 2018) that indicated the presence of a freshwater palustrine/lacustrine depositional system connected to a low energy stream/river in the region. A new adapisoriculid mammal Bharatlestes kalami was identified from the early Eocene Cambay Shale sediments of western India (Kapur et al., 2017a, 2017b). Phylogenetic analysis suggested that Bharatlestes is derived from the older genera Deccanolestes and Afrodon and primitive compared to European Bustylus and Adapisoriculus. Overall, this data provided evidence for the continued survival of a Gondwanan mammal lineage following the Deccan volcanic activity (Cretaceous-Palaeogene transition) in the Indian Subcontinent. Prasad et al. (2018a) provided new evidence (based on palynomorphs) from an inland location in the Deccan province suggestive of the existence of a shallow marine embayment in central India during the late Maastrichtian. The study supported "Out of India" dispersal of dipterocarps based on evidence of fossil pollen of Dipterocarpaceae. A fossil leaf of Aporosa Blume (Phyllanthaceae) from the Paleogene of the Indian subcontinent supported the origin of the genus on the Indian subcontinent, and subsequent dispersal to Southeast Asia (Shukla et al., 2016). Besides, a record of Chisocheton (Meliaceae), Dioscorea eocenicus (Dioscoreaceae), Holigarna grahamii (Anacardiaceae) and associated fossil flora indicated the presence of tropical evergreen forests in western India during the early Paleogene (Shukla and Mehrotra, 2018, 2019; Shukla et al., 2018).

A study carried out from northeast India indicated that ancestors of 'sweet potato' originated in India (Srivastava et al., 2018a). Numerous fossil woods from the northeast of India were also recorded from the late Miocene Tipam Group of Tripura and late Oligocene sediments of Assam (Mehrotra et al., 2017; Mehrotra and Srivastava, 2017; Rajkumar et al.,2017). Of these, fossils of Shorea represent the first record of angiosperm wood from Manipur, while Careyais the first record of the genus from the Palaeogene sediments. Numerous Priabonian age calcareous nannofossils have also been reported from the Rewak Formation, Meghalaya (Singh et al., 2016). Sarkar (2016) conducted a microfacies analysis in a palaeoenvironmental framework of the early Eocene Umlatdoh Limestone (Meghalaya) based on the fossil evidence on calcareous algae and foraminifers. Prasad et al. (2018b) carried out a multi-proxy study (i.e., incorporating sequence-, bio-stratigraphy, palynology, NLR approach) on the upper Paleocenelower Eocene Jathang section, Meghalaya in a palaeoclimatic and palaeoenvironmental context. A co-existence analysis was carried on the Jathang pollen fossils that suggested very humid climatic conditions during the extreme global warming event globally known as Paleocene Eocene Thermal Maxima (PETM) event at 55.5 Ma.

Combined palynological and stable carbon isotope $\left({ }^{13} \mathrm{C}\right)$ investigations were compiled in the lignite sequence at Panandhro, Kutch Basin, Gujarat (Agrawal et al., 2017). Dinoflagellate cysts and associated spore-pollen assemblage assign an early Eocene (Ypresian) age to the lignitic succession at Panandhro. Furthermore, a pronounced negative carbon isotope excursion of about $2.7 \%$, correlated to the globally significant hyperthermal event, second Eocene Thermal Maximum (ETM2), was discovered in the middle part of the succession, consistent with the palynological constraints. This is the first record of a hyperthermal event (ETM2) from the Kutch Basin. Earlier, Mathews and Singh (2016), utilizing FTIR, pyrolysis and GC-MS analysis, characterized the handpicked solid bitumen (viscous residue of 
hydrocarbon) found as fillings in the lignite of the Panandhro field, Gujarat. Detailed collaborative studies to understand the palaeodepositional history of the early Paleogene lignite sequences of western India by utilizing organic petrography, palynology and palynofacies were also carried out in detail (Singh et al., 2017a, 2017b; Matthews et al., 2018). A palynological and palynofacies analysis of the early Eocene lignitic sediments at Gurha Lignite Mine was carried out by Kumar et al. (2016).

The collaborative studies on the amber biota from the early Eocene lignite associated sequences of western India have recorded the insect fossils of family Chironomidae (represented by 192 specimens belonging to five subfamilies) for the first time in India (Stebner et al., 2017a). Earlier, indirect evidence for pheromone-mediated mating behavior was recorded from a new species (Camptopterohelea odora) of biting midge preserved within the $54 \mathrm{Ma}$ Indian amber (Stebner et al., 2016). In a separate study, seven extant and three fossil genera of biting midges were recorded from Cambay amber, and five new species were described (Stebner et al., 2017b). Interestingly, this study suggested faunal exchange between Europe, Asia and India before the early Eocene.

An extensive study based on 82 species of planktic and benthic diatoms belonging to 32 genera (recovered from 21 outcrop samples from Neil Island, Andaman, and Nicobar Islands) including that of Ocean upwelling diatom species Thalassionema nitzschioides, Chakraborty and Ghosh (2016) provided evidence for prevalence of a robust monsoonal system with weaker intermittent monsoonal activity in the region during the late Miocene (Tortonian).

In a collaborative study based on CLAMP (Climate LeafAnalysis Multivariate Program) analysis on leaf fossils from the southern Tibet and the Himalayan foreland basin, and utilizing data on agebased on U-Pb dating on zircons, Ding et al. (2017) quantified the rise of the Himalayan. In separate collaborative work, a proxy of carbonate distribution within paleosol profiles was utilized to infer the appearance of monsoonal circulation of new strength in the Himachal Pradesh segment of the Himalayan foreland by at least 20 My ago (Retallack et al., 2018). Spicer et al. (2017), based on the CLAMP analysis of the Paleogene fossil leaves from India and China, suggested that an Indonesian-Australian type of Monsoon system was present in the region. A fossil leaf of coryphoid palm reported from the Late Oligocene sediments of Lunpola Basin (Central Tibet) suggested that a valley system was present in the region (Tao et al., 2019). Lagerstroemia L. fossil wood was recorded from the late Miocene sediments of Ladakh and indicated the prevalence of warm and humid climate in the region (Srivastava et al., 2018b). In another collaborative study, a recent discovery of Ailanthus fossil from the Late Oligocene sediments of central Tibet indicated a floristic exchange between India and Eurasian plates (Liu et al., 2019).

Concerning the Neogene biotic records, the institute scientists recorded both fauna and flora from the western and northeastern regions of India. Bhandari et al. (2018) reported evidence of hominoid (Sivapethicus) remains from the late Miocene sediments of Kutch, Gujarat. Kapur et al. (2019) recorded numerous microcoprolites (representing three morphotypes) linked to ichthyophagous fishes from the Aquitanian (Miocene) Khari Nadi Formation of Kutch, Gujarat. Various fossil woods were recorded from the Middle and Upper Siwalik sediments of Arunachal Pradesh, indicating less seasonality in temperature and rainfall in the region (Srivastava et al., 2018c; Mehrotra et al., 2018).

\section{Quaternary}

\section{Himalayan Region}

The Quaternary research going on at the BSIP has a wide range of working aspects based on various biotic and abiotic proxies to decipher palaeoclimate and palaeoecology from large geospatial extents. From the eastern Himalaya region, transfer function model for quantitative past climate reconstruction was developed for various climatic variables using the modern pollen-climate dataset (Ghosh et al., 2017) which suggested that winter temperature was the dominant controlling factor for the glacial changes across the Last Glacial Maxima (LGM) in the eastern Himalaya. Ghosh et al. (2018) studied hydroclimatic variability and corresponding vegetation response in the Darjeeling Himalaya, India, over the past $\sim 2400$ years using multi-proxy records. This study identified a humid climatic phase at the beginning of the last 
millennium, a pre-Medieval Warm Period (MWP) less humid phase, while MWP was wetter than the former stage and a wet Little Ice Age (LIA) in the Darjeeling Himalaya. A study based on multi-proxy records on glacial outwash sedimentary profile of Sikkim, eastern Himalaya showed decadal to centennial-scale records and identified five positives and three negative excursions of the Indian Summer Monsoon (ISM) since last $\sim 13 \mathrm{ka}$ (Ali et al., 2018). The most prominent abrupt negative ISM shift was observed during the termination of the Younger Dryas (YD) between $\sim 11.7$ and $11.4 \mathrm{ka}$. The high elevation lake catchment of Arunachal Pradesh, eastern Himalaya, recorded environmental changes around $4.2 \mathrm{cal} \mathrm{yr}$ BP (Mehrotra et al., 2019). There were episodes of monsoon intensification during the Mid Holocene, followed by low temperatures and high aridity conditions during the abrupt climate change event period of the early Late Holocene. Pollen analysis has also been carried out on sedimentary core from Loktak Lake (the biggest freshwater lake in Manipur state, northeast India) recorded vegetation and climate of the region during the Late Holocene (Tripathi et al., 2018).

Vegetation and climate during later part of Pleistocene to a significant portion of Holocene ( $~ 16.6-$ $3.5 \mathrm{ka}$ ) have been reconstructed based on the palynological and magnetic susceptibility proxies from Kinnaur, western Himalaya (Ranhotra et al., 2018). The distinct spike in the magnetic susceptibility values between $\sim 8.7$ and $\sim 7.8 \mathrm{ka}$ marked as a global $8.2 \mathrm{ka}$ cool event. The palynological study carried out from the wetlands of Jammu and Kashmir recorded four phases of variations in the ISM precipitation, i.e., decreased monsoon precipitation during $\sim 8536-5296$ cal yr BP, increased monsoon precipitation during 5296-2776 cal yr BP, further increase in monsoon precipitation during $2776-1336$ cal yr BP and decrease in monsoon precipitation during $\sim 1336 \mathrm{cal}$ yr BP to present (Quamer, 2019). Additionally, a palaeolake sequence along the River Indus of the Ladakh sector studied for sedimentological characteristics sheds light on depositional environmental changes within the lake from postLGM to $5 \mathrm{ka}$ (Nag et al., 2016).

\section{Central India}

The palynological studies from the Core Monsoon
Zone of India recorded palaeoclimate for the Mid to Late Holocene period. The Mid-Holocene pollen records from SW Madhya Pradesh reported a dry climate during 5679-4939 cal yr BP that changed to warm and humid conditions with increased monsoonal precipitation between 4939-3762 cal yr BP (Quamar and Nautiyal, 2016). The pollen records from Chhattisgarh (Quamer et al., 2017) showed a humid climate probably indicative of moderate monsoon precipitation between $\sim 3796$ and $\sim 2428$ cal yr BP, which subsequently turns into the warm and relatively more humid climate with increased monsoon precipitation during $\sim 2428$ and $\sim 1431 \mathrm{cal} \mathrm{yr} \mathrm{BP}$. The ISM variability during the Holocene from $\mathrm{CMZ}$ of central India was studied based on multi-proxy records and identified the weakening and enhancement of monsoon intensity in different periods of Holocene (Kumar et al., 2019).

The palynological analysis coupled with sediment grain parameters carried out on lacustrine sediments of eastern Ganga Plain showed ISM variability since 1350 A.D (Saxena and Singh, 2017). The signals of weak monsoon recorded in this proxy record around 1650,1770 , and 1850 A.D. are synchronous with the LIA. In addition to pollen study, diatoms in Lahuradewa lake sediments, Ganga Plain support the contention that the human population was living in this area since early Holocene and agriculture activity started around $8 \mathrm{ka}$ (Thakur et al., 2018). Trivedi et al. (2019) highlighted the climate-induced changes in the vegetation, ecology and culture since $\sim 25500$ cal $\mathrm{yr}$ BP from the central Ganga plain and reported that during the last two millennium and until $\sim 1550 \mathrm{AD}$, the region was under immense human pressure of Kushana, Gupta and Mughal cultures, which is evident by the artifacts recovered. Similarly, the archaeobotanical dataset produced from the region of Kutch, Gujarat, NW India, has revealed a dominance of millets (drought-resistant crops) during Late Holocene ( $4.2 \mathrm{k}$ cal yr BP), an example of human adaptation in response to climate variability (Pokharia et al., 2017).

\section{Coastal Zone}

In India, the coastal wetlands sustain millions of people and are more vulnerable to the effects of rise/fall in relative sea level and changes in marine ecosystems. Mangrove extinction and migration were assessed 
through palynological studies in sedimentary cores to address climate, relative sea level and its relation to geomorphology since 8420 cal yr BP in Krishna delta (Farooqui et al., 2016) and since $7000 \mathrm{cal} \mathrm{yr} \mathrm{BP} \mathrm{in}$ Cauvery delta (Srivastava and Farooqui, 2017). Results indicate climate-induced relative sea-level fluctuations highlighting the cooling event of $8.2 \mathrm{k} \mathrm{cal}$ yr BP from Kanuru site in Krishna delta and duration of intermittent rise/fall of relative sea-level during middle Holocene transgression (Farooqui et al., 2016). The results from Cauvery delta show that mangroves existed since 4000 cal yr BP in the Pichavaram estuary. During this period, evidence of marine palynomorphs have been recorded at present mean sea level in Vellar, Pichavaram, and Coleroon estuary but in TS Pettai it is about $4 \mathrm{~m}$ below current mean sea level indicating land subsidence of about $2-3 \mathrm{~m}$ in TS Pettai, the central part of Northeastern Cauvery delta providing a conducive environment for the growth and diversity of mangroves in this part of delta (Srivastava and Farooqui, 2017). Palynological study of surface sediments and shallow sedimentary cores from Pulicat lagoon post floods in Chennai after heavy rainfall in 2015 reveal indicator species of diatom as indicators of extreme events (Santhanam et al., 2016). A sediment core from Kukkal lake, Tamil Nadu, was studied for a continuous sediment record from 9000 cal yr BP to present (Rajmanickam et al., 2017). Climate proxies, including sediment texture, total organic carbon (TOC), total nitrogen, $\mathrm{C} / \mathrm{N}$, pollen and geochemical composition, indicate a steady progression to wetter conditions with two stepwise changes at about 8000, and between 3200-1800 cal yr BP. Another palynological study of an organic layer buried $\sim 80 \mathrm{ka}$ in Chaganacherry, Kerala, revealed a rich diversity of rainforest pollen amongst which the Basella pollen recorded shows central characters of two extant Basella species. Hence, the recovered pollen was ascertained as a new extinct species named as Basella keralensis sp. nov. (Farooqui et al., 2019). Surface sediments in the Vembanad wetland system, southwest India, were analyzed for metal contamination using individual and combined metal pollution indices (Manoj et al., 2018). The results show high heterogeneity of sediment characteristics, sources, sedimentary dynamics and geochemical processes. The main contaminated metal contribution appeared to be the anthropogenic input and small amount of the weathered rocks and sediments present in the course of the rivers.

\section{Polar Region}

BSIP is also involved in various Quaternary palaeoclimatic studies in the polar area (Antarctic and Arctic) and oceanic sector (Southern Ocean, Bay of Bengal, and the Arabian Sea). Geochemical and sedimentological analysis of the lake core (L-6) in the Schirmacher Oasis (SO), East Antarctica was conducted to understand the spatial and temporal extension of the paleoenvironmental evolution of the lakes in SO (Govil et al., 2016). The present study identified a colder phase (or re-advancement of the continental ice sheet) during the early to mid-Holocene and initiation of ice-free or continental ice-sheet retreat during the late Holocene and their implications on the productivity changes. The study of quartz grain morphology and microtexture along with sand percentage is used to reconstruct the paleoenvironmental changes in the Proglacial Lake situated in the Schirmacher Oasis, East Antarctica during the Holocene (Mazumdar et al., 2017). The study suggests probable alternative colder and less cold phases in the study area, which is also well supported by the respective sand percentages in the sediments. To understand the role of sedimentary processes and their periodicities to understand the forcing mechanism responsible for the regional climate variations, various sedimentary parameters and biogenic silica were used in the lake of SO, East Antarctica (Govil et al., 2018). The long-term trends in the data suggest the possible fluctuation of the Antarctic ice-sheet superimposed on global climatic fluctuations due to solar activity. Studies were also carried out in the Arctic region to understand past environmental changes. Quartz grain microtextures have been used to deduce the past environmental changes from the Ny-Alesund area, Svalbard, along with magnetic susceptibility data (Kar et al., 2018). Mid- and late Holocene is marked by a predominantly glacial environment characterized by meltwater streams originating from the glaciers and flowing into the fjord.

\section{Marine Records}

The high-resolution records of diatom frustules from the Southern Ocean sediment cores revealed the control of iron availability or other environmental conditions such as Sea Surface Temperature (SST) and/or sea ice presence on the morphometric variation of different diatom species. Shukla et al. (2016) 
reported the first study on modern sediments from the Southern Ocean to explore the variability of the mean valve area of Thalassiosima lentiginosa concerning productivity and current environmental conditions. T. lentiginosa means valve area variations in four deep-sea cores across the frontal zones in the Atlantic and Indian sectors of the Southern Ocean resulted from changes in SST and sea-ice presence modulating the species ability to make use nutrient stocks and controlling the length of its growing season, respectively. Shukla and Crosta (2017) suggested that more favorable SST, within the Fragilariopsis kerguelensis ecological range, during the Last Glacial period might have enabled $F$. kerguelensis to make better use of the low silica stocks prevailing in the subtropical zone leading to larger valves. Shukla and Romero (2018) studied F. kerguelensis size variation in core GeoB3606-1 collected in the Benguela Upwelling System, where F. kerguelensis valves were preserved during the glacial period $(68-30 \mathrm{ka})$ as a consequence of silicic acid leakage from polar to mid-latitudes. Nair et al. (2019) documented the interactions between Southern Hemisphere highlatitude (Antarctica \& Southern Ocean), southern Indian Ocean subtropics (Agulhas leakage), and Asian summer monsoon.

Based on new studies, the spatial distribution of organic-walled dinoflagellates cyst is studied in the 50 surface samples of eight transects from the western Bay of Bengal, to infer variation in the environmental conditions in the region (Uddandam et al., 2017). Statistical analyses indicate that salinity and silicates, as a significant source of nutrients, played a vital role in the distribution of dinoflagellate cyst in the Bay of Bengal. A new organic-walled dinoflagellate cyst Cristadinium striatiserratum has been reported from the modern sediments of the northern Indian Ocean (Uddandam et al., 2018). The study extends the geological range of the peridinioid species that consist of complete paratabulation from the Neogene to Holocene. The presence of Australasian microtektites was studied in U1452 core retrieved during the International Ocean Discovery Program (IODP) Expedition 354:Bengal Fan (Kawsar et al., 2018). Other than microtektites, the presence of a possibly polymetallicex solution structure (Widmanstätten texture), shocked minerals and unmelted and partly melted ejecta within the microtektite-bearing layer in the northern Indian
Ocean provides further evidence that the Australasian microtektites might have been formed by the impact of an extraterrestrial projectile at $\sim 0.8 \mathrm{Ma}$, somewhere in Indo-China.

Paleoclimatic studies using multi-proxy records from the NE Arabian Sea revealed the variations in the shelf environment of the western continental margin of India (Azharuddin et al., 2017, 2019). The periodicities in the multi-proxy record consisted of similar cycles, which also match with previously reported solar insolation influenced Southwest Monsoon (SWM) and other global and regional cycles. The observations suggested that the solar insolation was a leading factor responsible for the SWM trends during the Holocene, which might have further influenced the productivity, regional sea-level fluctuations and depositional conditions in the NE Arabian Sea.

\section{Tree-ring Studies}

Tree-ring studies from the Himalaya region were carried out on various aspects such as climate reconstruction, glacial behavior, and tree-line dynamics. In the western Himalaya region, tree-rings of Cedrus deodara and Pinus gerardiana were used to reconstruct boreal spring (March-May) precipitation covering the last millennium (1030-2011 C.E.) and established its large-scale consistency with hydrological records from westerly-dominated regions in Central Asia (Yadava et al., 2016). The behavior of western Himalayan glaciers for the past four centuries was studied using tree-ring based reconstructed glacial mass balance data (Shekhar et al., 2017), which showed that the fluctuation of the Himalayan glaciers largely depends on oceanic currents and total solar irradiance. Three different climatic reconstructions for Jammu and Kashmir, Northwest Himalaya, were developed using tree-rings data of conifers. These are a 275-year (1740-2014 C.E.) eight-month May SPI reconstruction (Singh et al., 2017c), April-June precipitation from 1723 to 2013 C.E. (Shah et al., 2018) using C. deodara and compared with the documented extreme flood, famines and drought events in Kashmir Valley. The winter (November-March) temperature reconstruction (1840-2012 C.E.) from Kashmir valley based on treering of Pinus wallichiana recorded marked warming trend at the beginning of the late twentieth century till 
2012 (Shah et al., 2019). From the eastern Himalaya region, a first tree-ring chronology of broad-leaved taxon, Toona ciliata, was developed (Shah and Mehrotra, 2017). Besides, the impact of climate change on treeline dynamics using tree-rings was investigated, which showed that $P$. wallichiana had shifted towards the upper elevation with varying rates of 11-54 m/10 yrs (Yadava et al., 2017).

\section{Ancient DNA Studies}

In addition, BSIP also conducted the largest-ever study of ancient human DNA in South Asia and sequenced the first genome of an individual from the ancient Indus Valley Civilization, which revealed unprecedented shifting ancestry of central and south Asian populations over time. The research on similar aspects also answered longstanding questions about the origins of farming and the source of Indo-European languages in South Asia. The first ancient human genome from mature Indus valley civilization has revealed no evidence of ancestry from Central Asia, Steppe, and Early Iranian farmers disprove the hypothesis that Agricultural practices in Indus Valley Civilization were expanded from Neolithic Iran (Shinde et al., 2019).

\section{Publications}

Aggarwal N, Thakur B and Jha N (2019) Palaeoenvironmental changes in the Lower Gondwana succession of the Godavari Graben (South India) inferred from palynofacies Journal of Paleolimnololgy 61 329-343

Agnihotri A, Pandita S K, Tewari R, Awatar R, Linnemann U, Pillai S S K, Joshi A, Gautam S and Kamlesh K (2018) Palynology and detrital zircon geochronology of the Carboniferous Fenestella Shale Formation of the Tethyan realm in Kashmir Himalaya: implications for global correlation and floristic evolution Journal of Asian Earth Sciences 157 349-359

Agrawal S, Verma P, Rao M R, Garg R, Kapur V V and Bajpai S (2017) Lignite deposits of the Kutch Basin, western India: carbon isotopic and palynological signatures of the early Eocene hyperthermal event ETM2 Journal of Asian Earth Sciences 146 296-303

\section{Modern Pollen Analogues}

Studies on modern pollen analogues have long been a valuable tool used in the qualitative and quantitative reconstruction of vegetation and environment of Quaternary. Recently, modern palynological studies from coastal wetlands (Srivastava et al., 2019; Pandey and Minckley, 2019), high altitudinal regions of Himalayas (Dubey et al., 2017; Ghosh et al., 2017; Bajpai and Kar, 2018; Quamar et al., 2018; Roy et al., 2018), northeastern region of India (Tripathi et al., 2017; Basumatary et al., 2018), North India (Trivedi et al., 2016; Saxena et al., 2017; Bera et al., 2018) and central India (Quamar and Bera, 2019) have assessed its potential in the interpretation of fossil pollen records to reconstruct past climate in tropical, sub-tropical and temperate zones at different timescales during the Quaternary.

\section{Conclusions}

The contributions from more than 250 staff members of the BSIP, including the scientific, technical, and administrative personnel, have brought forth the research accomplishments of BSIP, Lucknow. The constant zeal to seek excellence and put forth substantial results is the primary aim for each member of the institute. Staff at BSIP is grateful to all the funding agencies for supporting the various scientific ventures leading to the success of institute.

Ali S N, Dubey J, Ghosh R, Quamar M F, Sharma A, Morthekai P, Dimri A P, Shekhar M, Arif M D and Agrawal S (2018) High-frequency abrupt shifts in the Indian summer monsoon since Younger Dryas in the Himalaya Scientific Report 89287

Ansari A H (2016a) Stable isotopic evidence for anaerobic maintained sulfate discharge in a polythermal glacier Polar Science 10 24-35

Ansari A H (2016b) Stable isotopic evidence for high microbial nitrate throughput in a High Arctic glacial catchment The Cryosphere Discussion doi: 10.5194/tc-2016-59

Ansari A H (2017) Prospect of studying Bijaigarh Shale, Vindhyan Supergroup, and its implication for Mesoproterozoic oxygenation Bulletin of Environmental and Scientific Research 6 8-13

Ansari A H, Pandey S K, Sharma M Agrawal S and Kumar Y (2018) Carbon and oxygen isotope stratigraphy of the 
Ediacaran Bilara Group, Marwar Supergroup, India: Evidence for high amplitude negative carbon-e isotopic excursions Precambrian Research 308 75-91

Ansari A H, Singh I B, Kumar S, Pandey S K and Kumar Y (2019) Note on the $\mathrm{C}$ and $\mathrm{O}$ stratigraphy of the Garbyang Formation (Malla Johar Area), Tethyan Himalaya, India Journal of the Palaeontological Society of India (accepted)

Azharuddin S, Govil P, Singh A D, Mishra R and Shekhar M (2019) Solar insolation driven periodicities in southwest monsoon and its impact on NE Arabian Sea paleoceanography Geoscience Frontiers doi: https:// doi.org/10.1016/j.gsf.2019.03.007

Azharuddin S, Govil P, Singh A D, Mishra R, Agrawal S, Tiwari A K and Kumar K (2017) Monsoon-influenced variations in productivity and lithogenic flux along offshore Saurashtra, NE Arabian Sea during the Holocene and Younger Dryas: A multi-proxy approach Paleogeography, Palaeoclimatology, Palaeoecology 483 136-146

Baas P, Manchester S R, Wheeler E A and Srivastava R (2017). A new Deccan fossil wood with dimorphic fibers: The oldest fossil Connaraceae? IAWA Journal 38 124-133

Bajpai R and Kar R (2018) Modern pollen deposition in glacial settings in the Himalaya (India): The abundance of Pinus pollen and its significance Palynology 42 475-482

Basumatary S K, Nautiyal C M, Ghosh R and Tripathi S (2018) Modern pollen deposition in wetlands of Majuli Island and its implication to decipher palaeoflood episodes in northeast India Grana 57 273-283

Bera S K, Tripathi S, Gupta S C and Bera S (2018) Pollen and spores in yellow rain from Lucknow, northern India Palynology 42 504-515

Bhandari A, Kay R F, Williams B A, Tiwari B N, Bajpai S and Hieronymus T (2018) First record of the Miocene hominoid Sivapithecus from Kutch, Gujarat state, western India PLOS ONE 45 e0217960

Chakraborty A and Ghosh A K (2016) Ocean upwelling and intense monsoonal activity based on late Miocene diatom assemblages from Neil Island, Andaman and Nicobar Islands, India Marine Micropaleontolology 127 26-41

Chinnappa C and Rajnikanth A (2016) A new species of Circoporoxylon from the Kota Formation (Jurassic), Pranhita-Godavari Basin, India and palaeobiogeography of the genus Ameghiniana 53 675-684

Ding L, Spicer R A, Yang J, Xu Q, Cai F, Lai Q, Wang H, Spicer T E V, Yue Y, Shukla A, Srivastava G, Khan MA, Bera S and Mehrotra R C (2017) Quantifying the rise of the Himalaya orogen and implications for the South Asian monsoon Geology 45 215-218
Dubey J, Ghosh R, Agarwal S, Quamar M F, Morthekai P, Sharma A, Gautam R K, Srivastava V and Ali S N (2017) Characteristics of modern biotic data and their relationship to the vegetation of the Alpine zone of Chopta Valley, North Sikkim, India: implications for palaeovegetation reconstruction The Holocene 28 363-376

Farooqui A, Joseph G R and Arti G (2019) An extinct species of Basella: pollen evidence from sediments ( $\sim 80 \mathrm{ka})$ in Kerala, India Grana 58 399-407

Farooqui A, Ranjana and Nautiyal C M (2016) Deltaic land subsidence and sea-level fluctuations along the east coast of India since $8 \mathrm{ka}$ : A palynological study The Holocene $\mathbf{2 6}$ 1426-1437

Ghosh R, Biswas O, Paruya D K, Agrawal S, Sharma A, Nautiyal C M, Bera M and Bera S (2018) Hydroclimatic variability and corresponding vegetation response in the Darjeeling Himalaya, India over the past 2400 years Catena 170 8499

Ghosh R, Bruch AA, Portmann F, Bera S, Paruya D K, Morthekai $P$ and Ali S N (2017) A modern pollen climate dataset from the Darjeeling area, eastern Himalaya: Assessing its potential for past climate reconstruction Quaternary Science Review 174 63-79

Govil P, Mazumder A, Asthana R, Tiwari A and Mishra R (2016) Holocene climate variability from the lake sediment core in Schirmacher Oasis region, East Antarctica: Multiproxy approach Quaternary International 425 453-463

Govil P, Mazumder A, Ram R, Singh D S and Azharuddin S (2018) Meltwater flux and climate change record of last 18.5 ka from Schirmacher Oasis, East Antarctica Polar Science 18 135-141

Jasper A, Agnihotri D, Tewari R, Spiekermann R, Pires E F, Augusto S D R A and Uhl D (2017) Fires in the mire: Repeated fire events in Early Permian 'peat-forming' vegetation of India Geological Journal 52 955-969

Jha N, Aggarwal N and Mishra S (2018) A review of the palynostratigraphy of Gondwana sediments from Godavari Graben, India: Global comparison and correlation of Permian-Triassic palynoflora Journal of Asian Earth Sciences 163 1-21

Jha N, Joshi H and Mishra S (2016) Record of Gondwana plant mega- and microfossils in Nimugudem area, Telangana, India: Palynodating and palaeoenvironmental interpretation Current Science 111 416-424

Kapur V V, Das D P, Bajpai S and Prasad G V R (2017a) First mammal of Gondwanan lineage in the early Eocene of India Comptes Rendus Palevol 16 721-737 
Kapur V V, Das D P, Bajpai S and Prasad G V R (2017b) Corrigendum to "First mammal of Gondwanan lineage in the early Eocene of India" [C.R. Palevol, Kapur et al., 16 (2017)] Comptes Rendus Palevol 16820

Kapur V V, Khosla A and Tiwari N (2018) Palaeoenvironmental and palaeobiogeographic implications of the microfossil assemblage from the Late Cretaceous intertrappean beds of the Manawar area, District Dhar, Madhya Pradesh Historical Biology doi: 10.1080/08912963.2018.1425408

Kapur V V, Kumar K, Morthekai P and Chadda A (2019) Palaeodiet of Miocene producer(s) and depositional environments(s): Inferences from the first evidence on Microcoprolites from India Acta Geologica Sinica-English Edition. doi: 10.1111/1755-6724.14293

Kar R, Mazumdar A, Mishra K, Patil S K, Ravindra R, Ranhotra P S, Govil P, Bajpai R and Singh K (2018) Climatic history of Ny-Alesund region, Svalbard, over the last 19,000 yr: Insights from quartz grain microtexture and magnetic susceptibility Polar Science 18 189-196

Kathal P K, Srivastava R, Mehrotra R C and Alexander P O (2017) Rhizopalmoxylon nypoides-a new palm root from the Deccan Intertrappean beds of Sagar, Madhya Pradesh, India Journal of Earth System Science 12635 doi: 10.1007/ s12040-017-08151

Kawsar M, Manoj M C, Yoshida K, Baxter A and Reilly B T (2018) Morphological and chemical properties of microtektite grains from Bay of Bengal (IODP Expedition 354). AGU Fall Meeting 2018, Washington DC. ESSOAr. doi: 10.1002/essoar.10500240.1

Kumar K, Agrawal S, Sharma A and Pandey S (2019) Indian Summer Monsoon (ISM) variability and vegetation changes in Core Monsoon Zone (CMZ), India during the Holocene: A multiproxy study The Holocene 29 110-119

Kumar K, Tewari R, Agnihotri D, Sharma A, Pandita SK, Pillai S S K, Singh V and Bhat G D (2017) Geochemistry of the Permian-Triassic sequences of the Guryul Ravine section, Jammu and Kashmir, India: Implications for oceanic redox conditions Geo Res J 13 114-125

Kumar M, Spicer R A, Spicer T E V, Shukla A, Mehrotra R C and Monga $P$ (2016) Palynostratigraphy and palynofacies of the early Eocene Gurha lignite mine, Rajasthan, India Paleogeography, Palaeoclimatology, Palaeoecology 461 98-108

Kumar S and Ahmad S (2016) Problematic structures from the Ediacaran Jodhpur Sandstone, Rajasthan, India, and their possible affinity Journal of the Palaeontological Society of India 60 21-26

Limaye S S, Mogul R, Smith D J, Ansari A H, Slowik G P and
Vaishampayan P (2018) Venus' spectral signatures and the potential for life in the clouds Astrobiology 18 11811198

Liu J, Spicer R A, Tang H, Deng W Y D, Wu F X, Srivastava G, Spicer T E V, Do T V, Deng T and Zhou Z K (2019) Biotic interchange through lowlands of Tibetan Plateau suture zones during Paleogene Paleogeography, Palaeoclimatology, Palaeoecology 524 33-40

Manoj M C, Thakur B, Uddandam P R and Prasad V (2018) Assessment of metal contamination in the sediments of Vembanad wetland system, from the urban city of southwest India Environmental Nanotechnology, Monitoring \& Management 10 238-252

Mathews R P and Singh B D (2016) Characterization of solid bitumen from Panandhro lignite (western India) based on FTIR and Pyrolysis GC-MS study Current Science 111 $1842-1846$

Mathews R P, Singh, B D, Singh H, Singh V P and Singh A(2018) Characterization of Panandhro Lignite Deposits (Kutch Basin), western India: Results from Bulk Geochemical and Palynofloral Compositions Journal Geological Society of India 91 281-289

Mazumder A, Govil P, Kar R, Gayathri N M and Raghuram (2017) Palaeoenvironments of a proglacial lake in Schirmacher Oasis, East Antarctica: Insights from Quartz grain microtexture Polish Polar Research 38 1-19

Mehrotra N, Shah S K, Basavaiah N, Laskar A H and Yadava M G (2019) Resonance of the ' 4.2 ka event' and terminations of global civilizations during the Holocene, in the palaeoclimate records around PT Tso Lake, Eastern Himalaya Quaternary International 50 206-216

Mehrotra R C and Srivastava G (2017) In situ Lecythidaceae wood from the Oligocene of Makum Coalfield, northeast India IAWA Journal 38 162-169

Mehrotra R C, Mehrotra N, Srivastava G and Shah S K (2017) Occurrence of fossil woods in the Unakoti District, Tripura and their palaeoclimatic significance Journal of Palaeontological Society of India 62 17-30

Mehrotra R C, Srivastava G and Srikarni C (2018) Lagerstroemia L. wood from the Kimin Formation (Upper Siwalik) of Arunachal Pradesh and its climatic and phytogeographic significance Journal Geological Society of India 91 695699

Mishra S, Aggarwal N and Neerja J (2017) Patterns of change across Permian-Triassic transition Boundary in Chintalapudi area, Godavari Graben, south India, and its palaeoenvironmental implications Palaeobiodiversity and Palaeoenvironment doi: 10.1007/s12549-017-0302-3 
Murthy S, Kavali P S, Mercedes di P and Chakraborti B (2018) Late Pennsylvanian and Early Cisuralian palynofloras from the Rajmahal Basin, Eastern India, and their chronological significance Historical Biology https://doi.org/10.1080/ 08912963. 2018.1529763

Murthy S, Mahesh S and Roy J S (2016) Palynopetrographical facet and depositional account of Gondwana sediments from East Bokaro Coalfield, Jharkhand Journal Geological Society of India $\mathbf{8 8} 549-558$

Nag D, Phartiyal B and Singh D (2016) Sedimentary characteristics of palaeolake deposits along the Indus River valley, Ladakh, Trans Himalaya: Implications for the depositional environment Sedimentology 63 1765-1785

Nair A, Mohan R, Crosta X, Manoj M C, Marieu V and MelothT (2019) Southern Ocean sea-ice and frontal changes during the late Quaternary and their linkages to Indo-Asian summer monsoon Quaternary Science Reviews $21393-$ 104

Pandey S and Minckley T (2019) Modern pollen-vegetation studies from the Sajnekhali Island Wildlife Sanctuary, Sundarbans, Eastern India Palynology 43 213-222

Pandey S K and Sharma M (2017) Enigmatic Ediacaran Megascopic bedding plane structures on the Sonia Sandstone, the Jodhpur Group, MarwarSupergroup, India: Seaweed or problematica? Geological Journal 52 784-807

Pandey S, Clark J, Nema P, Bonaccorsi R, Som S, Sharma M, Phartiyal B, Rajamani S, Mogul R, Martin-Torres J, Vaishampayan P, Black J, Stellar L, Srivastava A, Singh R, Mguirk S, Zorzano M P, Guttler J, Mendaja M, Salinas A, Ahmad S, Ansari A H, Singh V K, Mungi C and Bapat N (2019) Ladakh: Diverse, High-Altitude Extreme Environments for Off-Earth Analogue and Astrobiology Research International Journal of Astrobiology 1-21 https:/ /doi.org/10.1017/S1473550419000119

Pokharia A K, Agnihotri R, Sharma S, Bajpai S, Nath J, Kumaran R N and Negi B C (2017) Altered cropping pattern and cultural continuation with declined prosperity following an abrupt and extreme arid event at 4,200 yrs BP: Evidence from an Indus archaeological site Khirsara, Gujarat, western India PLOS ONE 12 e0185684

Prasad V, Farooqui A, Murthy S and Bajpai S (2018a) Palynological assemblage from the Deccan Valcanic Province, central India: Insights into early history of angiosperms and the terminal Cretaceous paleogeography of peninsular India Cretaceous Research 86 166-198

Prasad V, Utescher T, Sharma A, Singh I B, Garg R, Gogoi B, Srivastava J, Uddandam P and Joachimski M M (2018b) Low-latitude vegetation and climate dynamics at the
Paleocene-Eocene transition - A study based on multiple proxies from the Jathang section in northeastern India Paleogeography, Palaeoclimatology, Palaeoecology 497 139-156

Quamar M F (2019) Vegetation dynamics in response to climate change from the wetlands of Western Himalaya, India: Holocene Indian Summer Monsoon variability The Holocene 29 345-362

Quamar M F and Bera S K (2019) Aerobiological implications of the extracted palynomorphs from the modern tree barks of the Korba District, Chhattisgarh, central India Palynology 43 34-42

Quamar M F and Nautiyal C M (2016) Mid-Holocene pollen records from southwestern Madhya Pradesh, central India, and their palaeoclimatic significance Palynology 41 401411

Quamar M F, Ali S N, Pandita S K and Singh Y (2018) Modern pollen assemblages from Reasi (Jammu and Kashmir), India: a tool for interpreting fossil pollen records Grana 57 364-376

Rajkumar H S, Srivastava G, Mehrotra RC, Keithellakpam D S, Soibam I and Khaidem K S (2017) First report of Dipterocarpaceous fossil wood from Manipur Journal the Geological Society of India 89 321-324

Rajmanickam V, Achyuthan H, Eastoe C and Farooqui A (2017) Early Holocene to present palaeoenvironmental shifts and short climate events from the tropical wetland and lake sediments, Kukkal Lake, Southern India: Geochemistry and palynology The Holocene 26 1-14

Ranhotra P S, Sharma J, Bhattacharyya A, Basavaiah N and Dutta K (2018) Late Pleistocene - Holocene vegetation and climate from the palaeolake sediments, Rukti Valley, Kinnaur, Himachal Himalaya Quaternary International 479 79-89

Retallack G J, Bajpai S, Liu X, Kapur V V and Pandey S K (2018) Advent of strong south Asian monsoon by 20 million years ago The Journal of Geology 126 1-24

Roy I, Ranhotra P S, Shekhar M, Bhattacharyya A, Pal A K, Sharma Y K, Singh S P and Singh U (2018) Overrepresentation of some taxa in surface pollen analysis misleads the interpretation of fossil pollen spectra in terms of extant vegetation Tropical Ecology 59 327-338

Santhanam S, Farooqui A and Karthikeyan A (2018) Bloom of the diatom, Biddulphia sp. and ecology of Pulicat lagoon, Southwest India in the aftermath of the 2015 north east monsoonal rainfall Environmental Monitoring and Assessment 190636

Sarkar S (2016) Early Eocene calcareous algae and benthic 
foraminifera from Meghalaya, N-E India: A new record of microfacies and palaeoenvironment Journal Geological Society of India $\mathbf{8 8}$ 281-294

Saxena A and Singh D S (2017) Multiproxy records of vegetation and monsoon variability from the lacustrine sediments of Eastern Ganga Plain since 1350 A.D. Quaternary International 444 24-34

Saxena A, Singh K J, Cleal C J, Chandra S, Goswami S and Shabbar H (2019) Development of the Glossopteris flora and its end Permian demise in the Tatapani-Ramkola Coalfield, Son-Mahanadi Basin, India Geological Journal doi: $10.1002 /$ gj.3307

Saxena A, Trivedi A and Chauhan M S (2017) Pollen rain vis-àvis vegetation relationship in Kikartal, Raebareli District, Uttar Pradesh Journal of Palaeontological Society of India 62 121-127

Shah S K and Mehrotra N (2017) Tree-ring studies of Toonaciliata from subtropical wet hill forests of Kalimpong, eastern Himalaya Dendrochronologia 46 46-55

Shah S K, Pandey U and Mehrotra N (2018) Precipitation reconstruction for the Lidder Valley, Kashmir Himalaya using tree-rings of Cedrus deodara. International Journal of Climatology 38 758-773

Shah S K, Pandey U, Mehrotra N, Wiles G C and Chandra R (2019) A winter temperature reconstruction for the Lidder Valley, Kashmir, Northwest Himalaya based on tree-rings of Pinus wallichian Climate Dynamics doi: https://doi.org/ 10.1007/s00382-019-04773-6

Sharma M, Ahmad S, Pandey S K and Kumar K (2018b) On the ichnofossil Treptichnus pedum: inferences from the Nagaur Sandstone, Marwar Supergroup, India Bulletin of Geosciences 93 305-325

Sharma M and Shukla B (2019) Akinetes from Late Paleoproterozoic Salkhan Limestone ( $>1600 \mathrm{Ma})$ of India: A proxy for understanding life in extreme conditions Frontier of Microbiology 10 397doi: 10.3389/ fmicb.2019.00397

Sharma M and Shukla Y (2016) The palaeobiological remains of Owk Shale, Kurnool Basin: A discussion on the age of the Basin Journal of the Palaeontological Society of India $\mathbf{6 1}$ 175-187

Sharma M and Singh V K (2019) Megascopic carbonaceous remains from Proterozoic Basins of India. In Geological Evolution of the Precambrian Indian Shield, Springer DOI: 10.1007/978-3-319-89698-4 27

Sharma M, Pandey S K, Ahmad S, Kumar K and Ansari A H (2018a) Observations on the ichnospecies Monomorphichnus multilineatus from the Nagaur Sandstone
(Cambrian Series 2-Stage 4), Marwar Supergroup, India Journal of Earth System Sciences 127 Article 75

Sharma M, Tiwari M, Ahmad S, Gautam R, Shukla B, Singh V K, Pandey S K, Ansari AH and Shukla Y (2016) Palaeobiology of Indian Proterozoic and Early Cambrian successionsrecent developments Proceedings of the Indian National Science Academy 82 559-579

Shekhar M, Bhardwaj A, Singh S, Ranhotra P S, Bhattacharyya A, Pal A K, Roy I, Martín-Torres F J and Zorzano M P (2017) Himalayan glaciers experienced significant mass loss during later phases of little ice age Scientific Reports 7 10305

Shinde V, Narasimhan V, Swapan N R, Mallick, Mah M, Lipson M, Nakatsuka N, Nicole, Lawson A M, Michel M, Oppenheimer J, Stewardson K, Jadhav N, Kim Y J, Chaterjee M, Munshi A, Panyam A, Waghmare P, Yadav Y, Patel H, Kaushik A, Thangaraj K, Meyer M, Patterson N, Rai N and Reich D (2019) An Ancient Harappan Genome Lacks Ancestry from Steppe Pastoralists or Iranian Farmers Cell doi: https://doi.org/10.1016/j.cell.2019.08.048

Shukla A and Mehrotra R C (2018) A new fossil wood from the highly diverse early Eocene equatorial forest of Gujarat (western India) Palaeoworld 27 392-398

Shukla A and Mehrotra R C (2019) First record of Dioscorea from the early Eocene of northwestern India: Its evolutionary and palaeoecological importance Review of Palaeobotany and Palynology 261 11-17

Shukla A, Mehrotra R C and Ali S N (2018) Early Eocene leaves of northwestern India and their response to climate change Journal of Asian Earth Sciences 166 152-161

Shukla A, Mehrotra R C, Spicer R A and Spicer T E V (2016) Aporosa Blume from the paleoequatorial rainforest of Bikaner, India: Its evolution and diversification in deep time Review of Palaeobotany and Palynology 232 14-21

Shukla B and Sharma M (2016) A new assemblage of large-sized microfossils from the Salkhan Limestone (>1600 Ma), Semri Group, Vindhyan Supergroup, India Journal of the Palaeontological Society of India 61 287-299

Shukla S K and Romero O E (2018) Glacial valve size variation of the Southern Ocean diatom Fragilariopsis kerguelensis preserved in the Benguela Upwelling System, southeastern Atlantic Paleogeography, Palaeoclimatology, Palaeoecology 499 112-122

Shukla S K, Crespin J and Crosta X (2016) Thalassiosira lentiginosa size variation and associated biogenic silica burial in the Southern Ocean over the last 42kyrs Marine Micropaleontology 12 74-85

Shukla S K and Crosta X (2017) Fragilariopsis kerguelensis size 
variability from the Indian subtropical Southern Ocean over the last 42000 years Antarctic Science 29 139-146

Singh A, Rai J and Garg R (2016) Record of late Eocene (Priabonian) nannofossils from the lower part of the Rewak Formation, Garo Hills, Meghalaya, Northeastern India Journal of Palaeontological Society of India 61 91-97

Singh A, Shivanna M, Mathews R P, Singh B D, Singh H, Singh V P and Dutta S (2017a) Palaeoenvironment of Eocene lignite bearing succession from Bikaner-Nagaur Basin, western India: Organic petrography, palynology, palynofacies and geochemistry International Journal of Coal Geology 181 $87-102$

Singh V K and Sharma M (2016) Mesoproterozoic Organic Walled microfossils from the Chaporadih Formation, Chandarpur Group, Chhattisgarh Supergroup, Odisha India Journal of the Palaeontological Society of India 61 75-84

Singh V P, Singh BD, Mathews R P, Singh A, Mendhe V A, Singh P K, Mishra S, Dutta S, Shivanna M and Singh M P (2017b) Investigation on the lignite deposits of Surkha mine Saurashtra Basin, Gujarat), western India: their depositional history and hydrocarbon generation potential International Journal of Coal Geology 183 78-99

Singh V, Yadav R R, Gupta A K, Kotlia B S, Singh J, Yadava A K, Singh A K and Mishra K G (2017c) Tree ring drought records from Kishtwar, Jammu and Kashmir, northwest Himalaya, India Quaternary International 444 53-64

Spicer R, Yang J, Herman A, Kodrul T, Aleksandrova G, Maslova N, Spicer T, Ding L, Xu, Q, Shukla A, Srivastava G, Mehrotra R, Liu X and Jin J H (2017) Paleogene monsoons across India and South China: Drivers of biotic change Gondwana Research 49 350-363

Srivastava G, Mehrotra R C and Dilcher D L (2018a) Paleocene Ipomoea (Convolvulaceae) leave from India with implications for an East Gondwana origin of Convolvulaceae Proceeding of the National Academy of Sciences, USA 115 6028-6033

Srivastava G, Mehrotra R C and Srikarni C (2018c) Fossil wood flora from the Siwalik Group of Arunachal Pradesh, India and its climatic and phytogeographic significance Journal of Earth System Science 127 doi.org/10.1007/s12040-0170903-2

Srivastava G, Mishra S R, Barman P, Mehrotra R C and Tripathi S C (2018b) Lagerstroemia L. fossil wood from the Indus molasse sediments (possibly late Miocene) of TransHimalayan region and its phytogeographic and climatic significance Review of Palaeobotany and Palynology 255 $14-21$
Srivastava J and Farooqui A (2017) Holocene climate and relative sea-level changes in Cauvery river delta, India based on pollen and sedimentary records Journal of Paleontological Society of India 62 193-204

Srivastava J, Farooqui A and Seth P (2019) Pollen and vegetation relationship in surface sediments, Coringa mangrove ecosystem, India: palaeoecological applications Palynology 43 451-466

Stebner F, Baranow V, Zakrzewska M, Singh H and Gilka W (2017a) The Chironomidae diversity based on records from early Eocene Cambay amber, India, with implications on habitats of Diptera Paleogeography, Palaeoclimatology, Palaeoecology 475 154-161

Stebner F, Szadziewski R, Rühr P T, Singh H, Hammel J, Kvifte G M and Rust J (2016) A fossil biting midge (Diptera: Ceratopogonidae) from early Eocene amber with a complex pheromone evaporator Scientific Reports doi: 10.1038/ SREP34352

Stebner F, Szadziewski R, Singh H, Gunekel S and Rust J (2017b) Biting midge (Diptera: Ceratopogonidae) from Cambay amber indicate that the Eocene fauna of the Indian Subcontinent was not isolated PLoS One 12 1-24

Steller L H, Nakamura E Ota T, Sakaguchi C, Sharma M and Van Kranendonk M J (2019) Boron isotopes in the Puga geothermal system, India and their implications for the habitat of early life Astrobiology 19 1-15

Tao S, Farnworth A, Spicer R A, Huang J, Wu F X, Liu J, Li S F, Xing Y W, Huang Y J, Deng W Y-D, Tang H, Xu C L, Zhao F, Srivastava G, Valdes P J, Deng T and Zhou Z K 2019. No high Tibetan Plateau until the Neogene Scientific Advances 5 eaav2189

Thakur B, Saxena A and Singh I B (2018) Paddy cultivation during early Holocene: evidence from diatoms in Lahuradewa lake sediments, Ganga Plain Current Science 114 2106-2115

Tripathi S, Basumatary S K, Bera SK, Brahma M and Sarma G C (2017) A palynological study of natural honey from the Bongaigaon District of Assam, northeast India Palynology 41 389-400

Tripathi S, Singh R, Nautiyal C M and Thakur B (2018) Vegetation history, monsoonal fluctuations and anthropogenic impact during the last 2330 years from Loktak Lake (Ramsar site), Manipur, north-east India: a pollen-based study Palynology 42 406-419

Trivedi A, Saxena A and Chauhan M S (2016) Studies on pollen rain vis-à-vis vegetation relationship in Chaudhari-ka-Tal, Raebareli District, Uttar Pradesh Journal of Palaeontological Society of India 61 85-90 
Trivedi A, Saxena A, Chauhan M S, Sharma A, Farooquii A, Nautiyal C M, Yao Y F, Wang Y F, Li C S and Tiwari D P (2019) Vegetation, climate and culture in Central Ganga plain, India: A multi-proxy record for Last Glacial Maximum Quaternary International 507 134-147

Uddandam P R, Prasad V and Rai J (2017) Dinoflagellate cyst distribution in sediments of western Bay of Bengal: Role of sea surface conditions Paleogeography, Palaeoclimatology, Palaeoecology 483 31-48

Uddandam P R, Prasad V, Thakur B and Manoj M C (2018) Cristadinium striaospinosa, a dinoflagellate cyst from the tropical region Journal of Paleontological Society of India $6373-80$

Yadava A K, Bräuning A, Singh J and Yadav R R (2016) Boreal spring precipitation variability in the cold arid western Himalaya during the last millennium, regional linkages, and socio-economic implications Quaternary Science Reviews 144 28-43

Yadava A, Sharma Y K, Dubey B, Singh J, Singh V, Bhutiyani M R, Yadav R R and Misra K G (2017) Altitudinal treeline dynamics of Himalayan pine in western Himalaya, India Quaternary International 444 44-52. 